CZASOPISMO INŻYNIERII LADDOWEJ, ŚRODOWISKA I ARCHITEKTURY JOURNAL OF CIVIL ENGINEERING, ENVIRONMENT AND ARCHITECTURE

JCEEA, t. XXXII, z. 62 (4/15), październik-grudzień 2015, s. 395-404

\author{
Angelika RACZAK ${ }^{1}$ \\ Barbara MARKIEWICZ ${ }^{2}$ \\ Magdalena BATKO ${ }^{3}$
}

\title{
ANALIZA NUMERYCZNA ROZKLADU NAPRĘŻEŃ SKRĘCONEGO I OBCIĄŻONEGO ARKUSZA BLACHY FALDOWEJ
}

\begin{abstract}
Blachy fałdowe charakteryzuja się wysoką ortotropia geometryczna, co daje możliwość kształtowania różnorakich postaci powłokowych. Wykorzystanie dowolnej deformacji arkuszy blach w celu uzyskania urozmaiconych kształtów przekryć wymaga stosowania odpowiedniej procedury projektowej. Celem niniejszej pracy było określenie rozkładu naprężeń w skręcanym i obciążonym arkuszu blachy za pomocą metody elementów skończonych w programie ADINA 9.0. Analizę przeprowadzono na modelu powłokowym shell, przyjęto siatkę elementów skończonych ośmiowęzłowych. Wybrano blachę typu T85x0,72 o długości 5,0m i obciążono $1 \mathrm{kN} / \mathrm{m}^{2}$ na całej powierzchni. Blachę oparto na kierownicach zależnie od przypadku: prosta - prosta, prosta - łuk o promieniu $2 \mathrm{~m}$ lub prosta - łuk o promieniu $4 \mathrm{~m}$. W każdym z trzech przypadków modelowano obrót w postaci zadania przemieszczeń na końcach kierownic, w celu uzyskania kątów o wartości: $0^{\circ}, 5^{\circ}$, $10^{\circ}, 15^{\circ}, 20^{\circ}$. Następnie odczytano wyniki w postaci naprężeń zredukowanych, których średnia mieściła się w granicach od $0,2-5 \mathrm{MPa}$ w zależności od przypadku. Z przeprowadzonej analizy wywnioskowano, że wraz ze wzrostem kąta skręcania rosną naprężenia efektywne, zarówno średnie, jak i ekstremalne. Im większy kąt skręcania tym większa różnica między naprężeniem średnim a maksymalnym. Naprężenia były skoncentrowane w miejscach występowania łączników. Ponadto zmieniają się one w zależności od przypadku kombinacji podpór i od kąta skręcania. Znając kąt skręcania poszczególnych fałd w powłoce, niezależnie od rodzaju podparcia można określić przyrost szerokości arkusza oraz naprężeń efektywnych. Istnieje zatem ścisły związek pomiędzy zmianą szerokości fałdy, a zmianą naprężeń.
\end{abstract}

Słowa kluczowe: kształtowanie powłok, deformacja sprężysta, analiza MES, jednostkowy kąt skręcania

\footnotetext{
${ }^{1}$ Autor do korespondencji: Angelika Raczak, Politechnika Rzeszowska, al. Powstańców Warszawy12, 35-959 Rzeszów, angelikaraczak@prz.edu.pl

2 Barbara Markiewicz, Politechnika Rzeszowska, al. Powstańców Warszawy 12 35-959 Rzeszów, bmarkiewicz@stud.prz.edu.pl

${ }^{3}$ Magdalena Batko, Politechnika Rzeszowska, al. Powstańców Warszawy 12 35-959 Rzeszów, magdalenabatko89@gmail.com
} 


\section{Wstęp}

Blachy fałdowe mają wiele zastosowań w budownictwie, jednym z nich jest kształtowanie przekryć powłokowych. Dzięki ich wysokiej ortotropii geometrycznej istnieje możliwość uzyskania różnorodnych form powłokowych, nie tylko walcowych i paraboliczno-hiperbolicznych. Formy te nadawane są poprzez sprężystą deformację arkusza blach.

Wyróżniamy trzy podstawowe rodzaje deformacji arkuszy blach [1, 2, 3]:

- deformacja giętna, powstająca w wyniku swobodnego zginania arkusza blachy fałdowej, z zachowaniem prostoliniowości i równoległości jego tworzących;

- deformacja skrętna, powstająca w wyniku swobodnego skręcania arkusza blachy, w wyniku której tworzące są parami skośne;

- deformacja giętno-skrętna, powstająca w wyniku złożenia dwóch wymienionych wyżej deformacji.

Tak więc zakres deformacji jest wielki, co pozwala tworzyć postacie powłok dowolnie wygiętych lub skręconych, o dużej wyniosłości i dużych jednostkowych kątach skręcania arkuszy (Rys.1). Zastosowanie dowolnych powłokowych form geometrycznych wymaga przestrzegania odpowiedniej procedury projektowania, obejmującej dwie fazy: kształtowanie postaci geometrycznej powłoki oraz analizę wytrzymałościową ukształtowanej powłoki [4]. Przedstawione podejście obliczeniowe, opisane szczegółowo w pozycji [3], zostało poparte badaniami doświadczalnymi i analizami numerycznymi oraz realizacjami kilku obiektów.

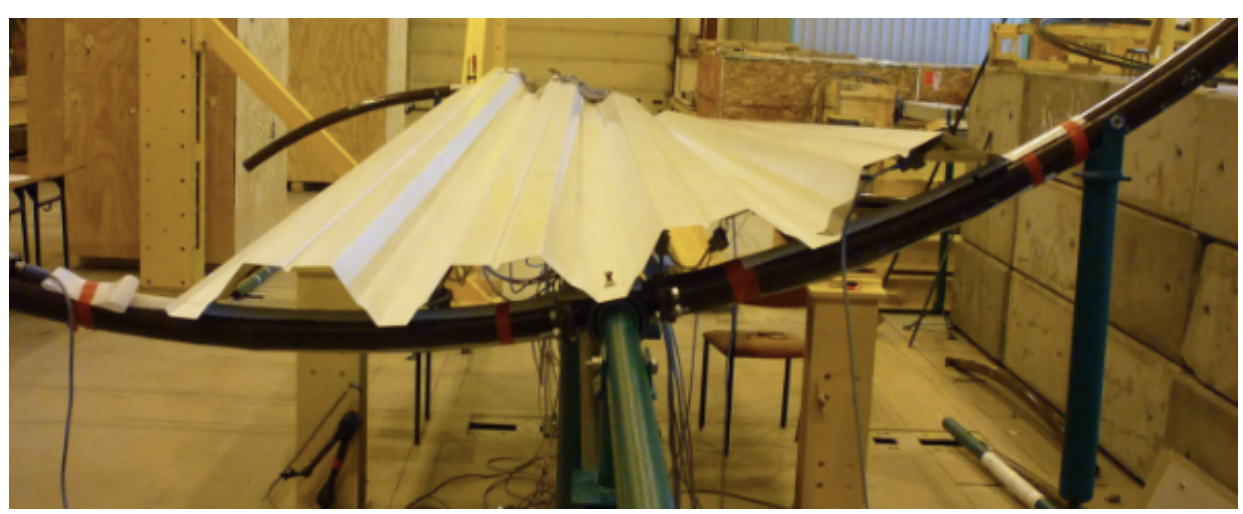

Rys. 1. Arkusz blachy fałdowej swobodnie skręcony i wygięty na stanowisku badawczym [5]

Fig. 1. Corrugated metal sheet twisted and bent on the test bench [5]

Projektowanie konstrukcji powłokowych $\mathrm{z}$ blach fałdowych musi opierać się na warunkach podanych w Eurokodzie 3, dla wyznaczonych wcześniej obciążeń i charakterystyk elementu. Niestety nie jest to łatwe, gdyż powłoka jako element 
powierzchniowy charakteryzuje się zmiennością obciążenia i geometrii zależnie od krzywizny konstrukcji. Dlatego też przy projektowaniu takich powłok należy przyjąć, że obiekt ten złożony jest z wielu prętów, z których każdy odwzorowuje pojedynczą fałdę blachy [6]. Spośród wszystkich prętów należy wybrać jeden najbardziej niekorzystny wytrzymałościowo, następnie dla niego zebrać obciążenie i przeprowadzić obliczenia. W tym celu należy obrać powłokowy, ortogonalny układ współrzędnych (Rys. 2), następnie rozłożyć działające

a)

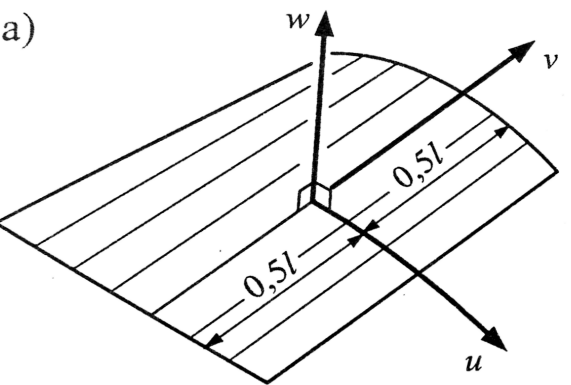

Rys. 2. Powłokowy układ współrzędnych [6]

Fig. 2. The curvilinear coordinate system of the shell [6]

obciążenie na składowe równoległe i prostopadłe do osi fałdy (Rys. 3a), następnie obciążenie prostopadłe rozdzielić na normalne i styczne do powłoki (Rys. 3b). Przekrój fałdy zginanej dwukierunkowo posiada zmienne na długości powłoki momenty bezwładności, z powodu jej krzywizny. Możliwe jest więc przeanalizowanie fałdy poprzez rozkład obciążenia na odpowiednie kierunki w odniesieniu do jej przekroju lub też ustosunkowanie obciążenia do różnych momentów bezwładności.

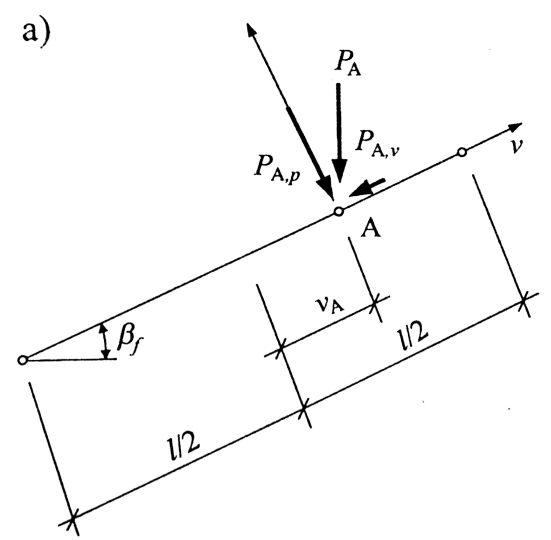

b)

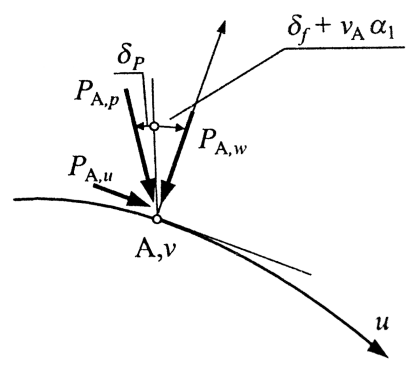

Rys. 3. Rozkład obciążenia na fałdzie [6]

Fig. 3. Load distribution on the fold [6] 


\section{Analiza numeryczna}

\subsection{Założenia}

Celem niniejszej pracy było przeprowadzenie badań symulacyjnych i określenie zachowania się skręconego i obciążonego arkusza blachy fałdowej. $\mathrm{Z}$ powodu ortotropowej budowy arkusza wybrano metodę elementów skończonych, która sprowadzała się do zbudowania modelu skręcanego arkusza w programie ADINA. Analizę przeprowadzono dla jednego rodzaju blachy fałdowej firmy RUUKKI T85, o grubości ścianki 0,72 mm (grubość bez powłoki ochronnej) i całkowitej długości arkusza 5,0 m (Rys.4). Przyjęto stałą wartość obciążenia zewnętrznego równomiernie rozłożonego na całej powierzchni powłoki (za wyjątkiem zakładki) o wartości równej $1 \mathrm{kN} / \mathrm{m}^{2}$ na kierunku $\mathrm{z}$. Obciążenie to może być interpretowane jako grawitacyjne obciążenie np. śniegiem, wręcz kluczowe dla tego rodzaju konstrukcji.

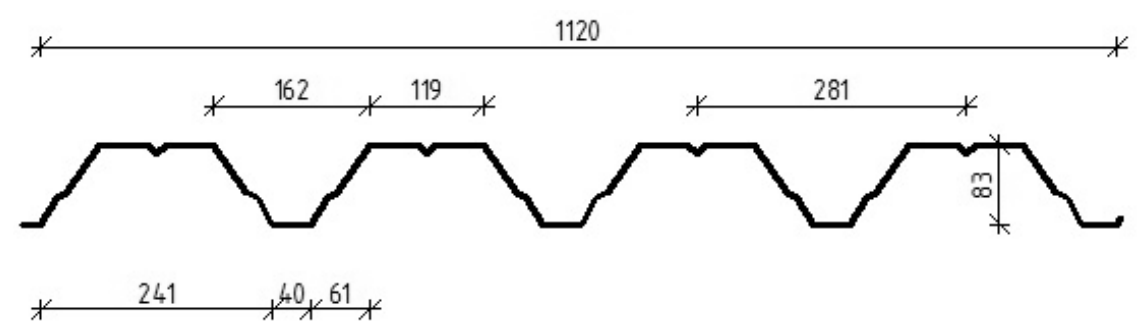

Rys. 4. Przekrój poprzeczny arkusza blachy fałdowej T85

Fig. 4. Cross section of the corrugated metal sheet $\mathrm{T} 85$

Parametrami zmiennymi były natomiast: kąt skręcania arkusza oraz rodzaj zastosowanych kierownic. Schematycznie analizowane przypadki skręcania arkusza dla poszczególnych kombinacji podpór przedstawiono na Rys. 5.
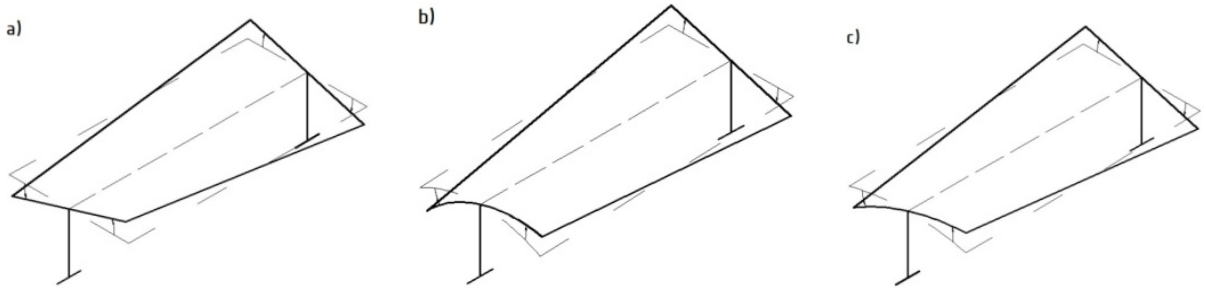

Rys. 5. Badane typy podparć: a) prosta - prosta, b)łuk $\mathrm{r}=2 \mathrm{~m}$ - prosta, c) luk $\mathrm{r}=4 \mathrm{~m}$ - prosta

Fig. 5. Considered types of supports: a) both straight, b) circular arc of $r=2 m$ - straight, c) circular arc of $\mathrm{r}=4 \mathrm{~m}$ - straight

Arkusz blachy ułożono pozytywnie i skręcano $w$ jedną stonę (jak na Rys. 5) o wartość: $0^{\circ}, 5^{\circ}, 10^{\circ}, 15^{\circ}$ i $20^{\circ}$. 


\subsection{Opis przyjętego modelu MES}

W ramach badań wykonano model MES, dla którego przeprowadzono symulację komputerową danego arkusza blachy fałdowej. Model wykonany został w programie ADINA (wersja 9.0). Arkusz blachy fałdowej zamodelowano za pomocą elementów powłokowych typu shell [7]. Zastosowano siatkę elementów prostokątnych 8-węzłowych o wymiarach: szerokość do zagięcia arkusza (fałdę z mocowaniem punktowym w środku podzielono dodatkowo symetrycznie w osi tych mocowań) i długość $100 \mathrm{~mm}$ (2350 elementów). Nie modelowano łączników. W odległości $100 \mathrm{~mm}$ od krawędzi zastosowano punktowe zamocowanie przegubowe xyz w dwóch punktach osi blachy, pozostała część blachy została oparta na kierownicach z wykorzystaniem metody kontaktu [7]. Kontakt zamodelowano w taki sposób, aby blacha mogła się swobodnie odkształcać, założono brak tarcia. Na Rys. 6 został przedstawiony widok modelu MES blachy fałdowej z programu ADINA.

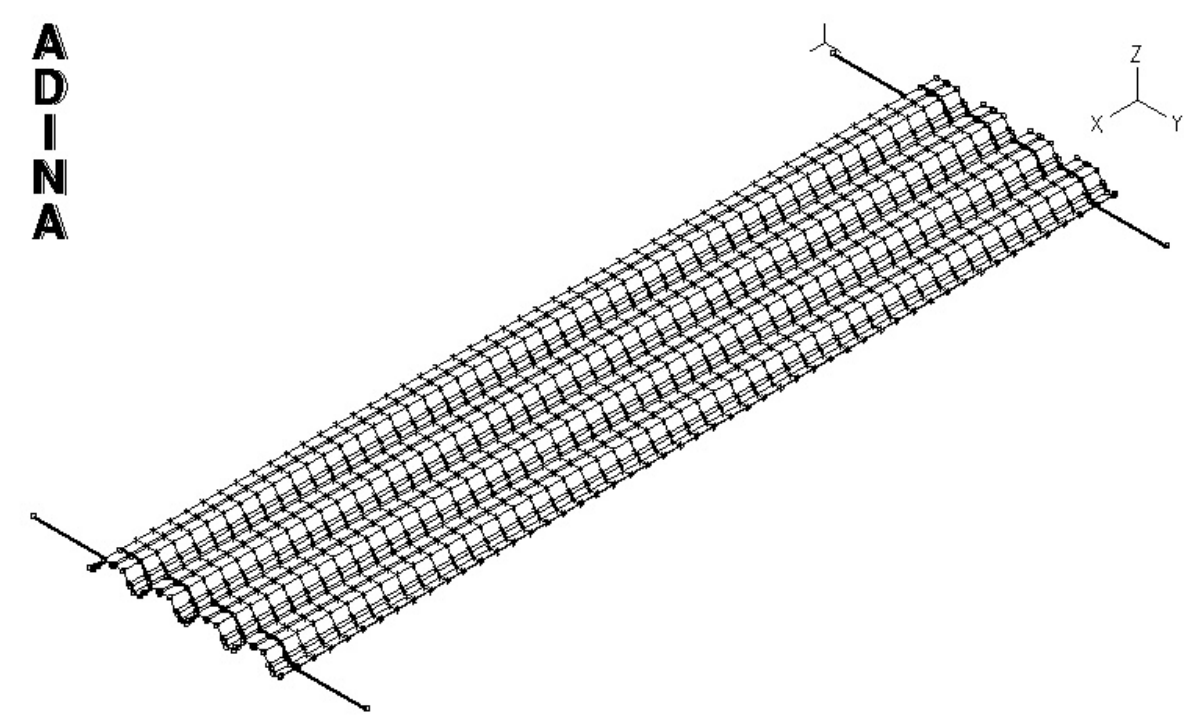

Rys. 6. Widok modelu MES blachy fałdowej z programu ADINA (kąt obrotu $0^{\circ}$ ).

Fig. 6. The finite element (FE) model of corrugated metal sheet in ADINA ( $0^{\circ}$ angle of rotation).

Materiał zamodelowano jako sprężysty izotropowy. Przyjęto moduł Younga równy $210 \mathrm{GPa}$, współczynnik Poissona 0,3 oraz gęstość $7860 \mathrm{~kg} / \mathrm{m}^{3}$. W obliczeniach uwzględniono ciężar własny blachy.

Obrót arkusza blachy fałdowej zrealizowano poprzez zadanie jako obciążenia przemieszczeń na końcach kierownic, tak aby uzyskać pożądany kąt obrotu. Podczas skręcania następowało zwiększenie szerokości arkusza w miejscu oparcia na kierownicach. 


\section{Analiza wyników symulacji komputerowych}

Tabela 1. Zestawienie wyników analizy numerycznej.

Table 1. Summary of the numerical analysis results.

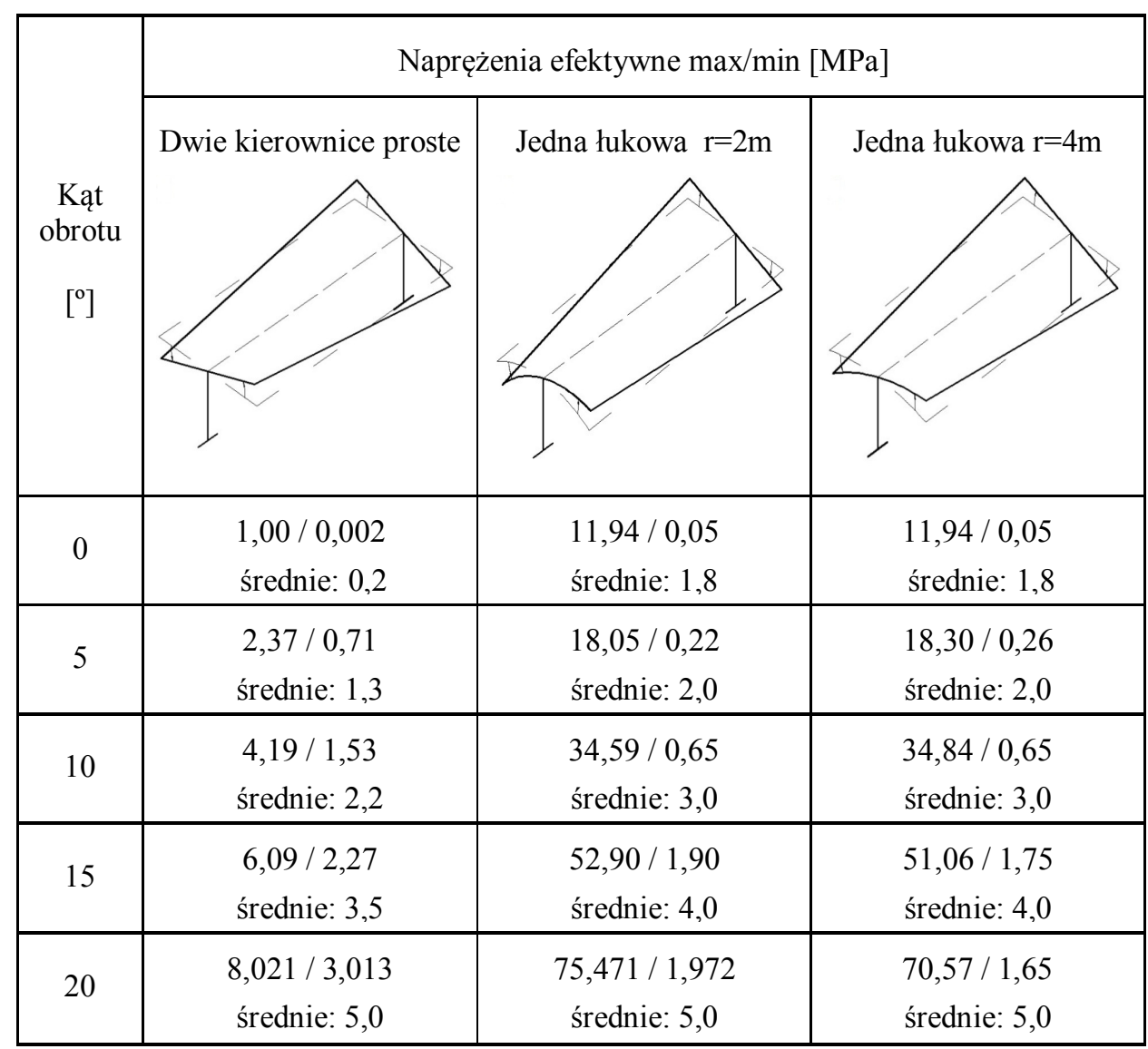

Wyniki analizy numerycznej przedstawiono w postaci tabeli (Tabela 1), która przedstawia minimalne, średnie i maksymalne naprężenia efektywne jakie otrzymano dla różnych przypadków skręcania arkusza i dla zadanych kombinacji podpór. Naprężenia efektywne przedstawiono w MPa. Średnia wartość naprężeń zredukowanych mieści się $\mathrm{w}$ granicach od 0,2-5 $\mathrm{MPa} \mathrm{w}$ zależności od zastosowanej kombinacji podpór.

Mapy naprężeń zredukowanych dla wybranych przypadków kombinacji podpór przedstawiono na Rys. 7. Naprężenia efektywne przedstawiono w kPa. 
a)

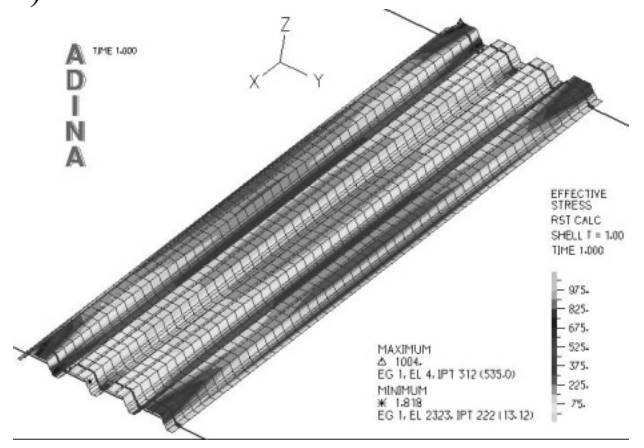

c)

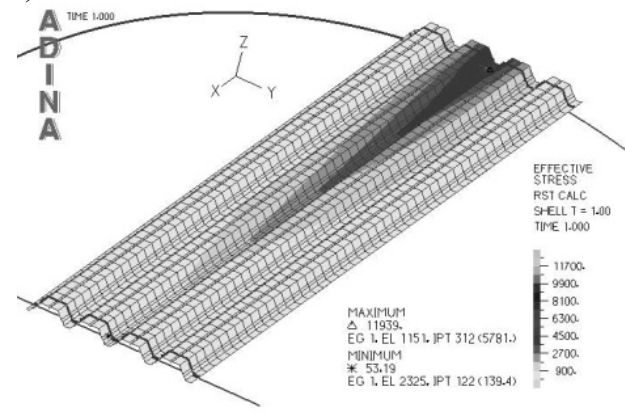

b)

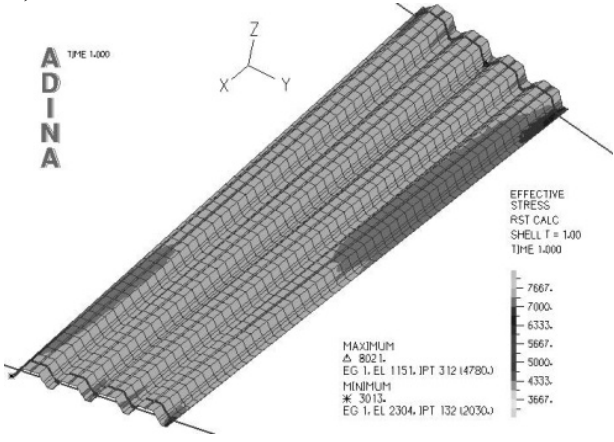

d)

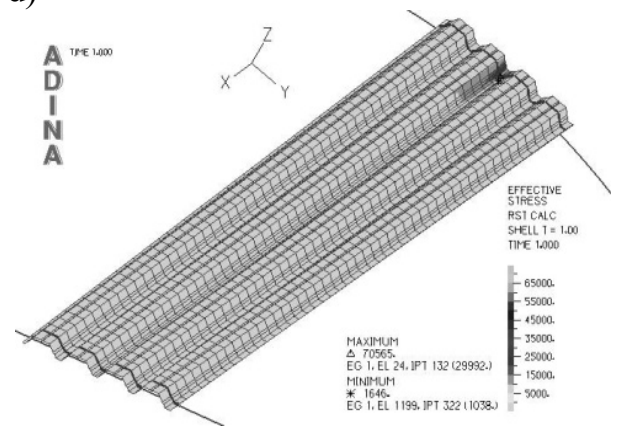

e)

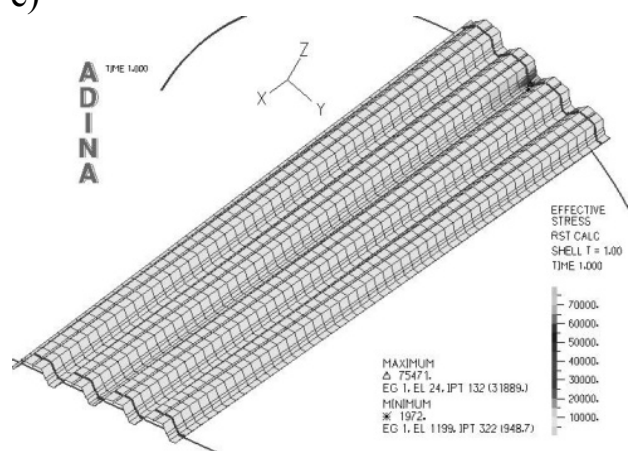

Rys. 7. Mapy naprężeń dla przypadków: a) kierownice proste, kąt $0^{\circ}$, b) kierownice proste, kąt $20^{\circ}$,

c) jedna kierownica łukowa or $=4 \mathrm{~m}$, kąt $0^{\circ}$, d) jedna kierownica łukowa o $\mathrm{r}=4 \mathrm{~m}$, kąt $20^{\circ}$, e) jedna kierownica łukowa or $=2 \mathrm{~m}$, kąt $20^{\circ}$.

Fig. 7. Maps of stress for different shaped supporting profiles: a) both straight, angle $0^{\circ}$, b) both straight, the angle of $20^{\circ}, \mathrm{c}$ ) one arc of $\mathrm{r}=4 \mathrm{~m}$, the angle of $0^{\circ}, \mathrm{d}$ ) one $\operatorname{arc}$ of $\mathrm{r}=4 \mathrm{~m}$, the angle of $20^{\circ}, \mathrm{e}$ ) one arc with $\mathrm{r}=2 \mathrm{~m}$, the angle of $20^{\circ}$. 
Jak widać rozkład naprężeń jest ujednolicony na całej blasze, za wyjątkiem miejsc występowania łączników. Dla przypadku z prostymi kierownicami, praca blachy była bardziej równomierna, a różnice pomiędzy naprężeniami średnimi i ekstremalnymi były stosunkowo niewielkie ze względu na styk występujący na całej szerokości blachy. Mapy naprężeń dla przypadków prosta - łuk o $\mathrm{r}=2 \mathrm{~m}$ i prosta - łuk o $\mathrm{r}=4 \mathrm{~m}$ wyglądają podobnie, widoczna jest koncentracja naprężeń w miejscach występowania łączników (Rys. 8a,b), w przeciwieństwie do przypadku z prostymi kierownicami (Rys. 8c), gdzie styk znajdował się na całej szerokości blachy.

a)

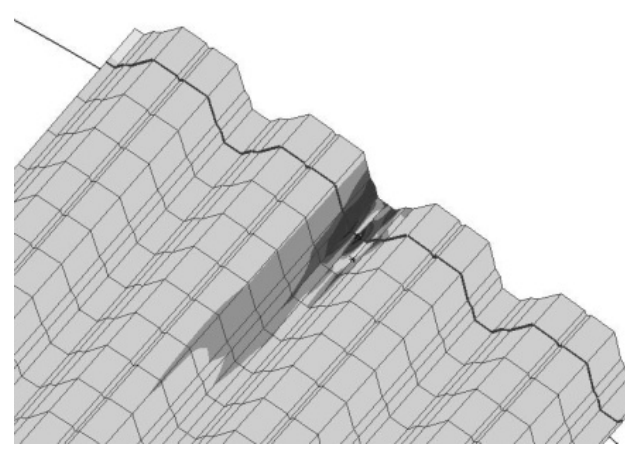

b)

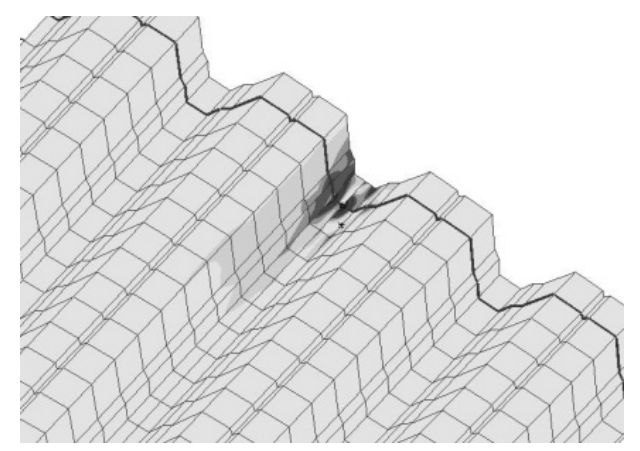

c)

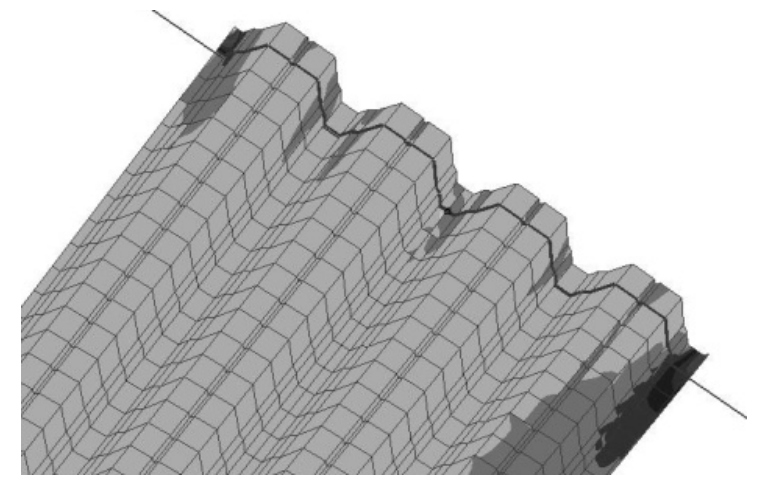

Rys. 8. Rozkład naprężeń w miejscach połączeń: a) jedna kierownica łukowa or $=2 \mathrm{~m}$, kąt $20^{\circ}$, b) jedna kierownica łukowa o $\mathrm{r}=4 \mathrm{~m}$, kąt $20^{\circ}$, c) kierownice proste, kąt $20^{\circ}$.

Fig. 8. Stress distribution in supported area: a) one arc of $r=2 \mathrm{~m}$, the angle of $20^{\circ}, \mathrm{b}$ ) one arc of $\mathrm{r}=4 \mathrm{~m}$, the angle of $20^{\circ}, \mathrm{c}$ ) both straight, the angle of $20^{\circ}$. 


\section{Podsumowanie i wnioski}

Blachy fałdowe mają wysoką ortotropię geometryczną, co daje możliwości kształtowania różnorakich postaci powłokowych. Powstają one dzięki sprężystej deformacji arkuszy. Poszczególne fałdy zmieniają swoją szerokość podczas skręcania powodują zginanie ścianek arkusza. Pojawiający się stan naprężeń w skręcanym arkuszu blachy fałdowej jest bardzo skomplikowany.

Analizując wyniki symulacji komputerowych można zauważyć, że wraz ze wzrostem kąta skręcania rosną naprężenia efektywne, zarówno średnie, jak i ekstremalne. Naprężenia te zmieniają się w zależności od stosowanej kombinacji podpór. W przypadku gdzie występowały dwie kierownice proste rozkład naprężeń był ujednolicony, a różnice pomiędzy naprężeniami były niewielkie. Wynikało to $\mathrm{z}$ tego, że styk występował na całej szerokości blachy. $\mathrm{W}$ przypadkach prosta-łuk widoczna jest koncentracja naprężeń w miejscach występowania łączników. Rozkład naprężeń dla przypadków prosta - łuk o $\mathrm{r}=2 \mathrm{~m}$ i prosta - łuk o $\mathrm{r}=4 \mathrm{~m}$ wyglądają podobnie ze względu na niewielką wartość obciążenia, blacha jest sztywna i opiera się wtedy w punkcie styku.

Znając kąt skręcania poszczególnych fałd w powłoce, niezależnie od rodzaju podparcia można określić przyrost szerokości arkusza oraz naprężeń efektywnych. Istnieje zatem ścisły związek pomiędzy zmianą szerokości fałdy, a zmianą naprężeń.

$\mathrm{Na}$ podstawie dotychczasowych podobnych badań numerycznych i doświadczalnych zrealizowanych na Politechnice Rzeszowskiej można stwierdzić poprawność otrzymanych wyników i wyciągniętych wniosków $[4,5,6]$.

\section{Literatura}

[1] Kiełbasa Z:: Modelowanie komputerowe skręcanego arkusza blachy fałdowej, Sympozjum Projektowanie koncepcyjne- kształtowanie konstrukcji, konstrukcje z blach fałdowych, konstrukcje cienkościenne: Sympozjum z cyklu „Nowe Osiągnięcia Nauki i Techniki w Budownictwie, Oficyna Wydawnicza Politechniki Rzeszowskiej, Rzeszów 2001.

[2] Kiełbasa Z.: Wytężenia w ściankach skręcanego arkusza blachy fałdowej, Budownictwo i Inżynieria Środowiska, z. 32, 2000, s. 224-232.

[3] Reichhart A.: Kształtowanie geometryczne i konstrukcyjne powłok z blach fałdowych, Oficyna Wydawnicza Politechniki Rzeszowskiej, Rzeszów 2002.

[4] Reichhart A.: Zasady kształtowania i analizy przekryć powłokowych z blach fałdowych, Inżynieria i Budownictwo, nr 9, 2012, s. 462-466.

[5] Wasilewski A.: Wpływ krzywizny powłoki z blach fałdowych na jej sztywność i nośność, Praca dyplomowa magisterska, Rzeszów 2013.

[6] Teliga A., Uliasz P.: Badania zmian postaciowych i odkształceń skręcanego i zginanego arkusza blachy fałdowej, Praca dyplomowa magisterska, Rzeszów 2011. 
[7] Bathe K.J.: Theory and Modeling Guide Volume I: ADINA Solids \& Structures, ADINA R\&D, Inc., Watertown 2012

\title{
NUMERICAL ANALYSIS OF STRESS DISTRIBUTION FOR TWISTED AND LOADED CORRUGATED METAL SHEETS
}

\begin{abstract}
S u m m a r y
Corrugated sheets are highly geometrically orthotropic structures, what gives the opportunity to create the various forms of shells. The use of any deformation of the metal sheet in order to achieve varied shaped cladding or roofing requires an appropriate design procedure.

The aim of this study was to determine stress distribution in the twisted and loaded sheet using the finite element method software - ADINA 9.0. The analysis was conducted with the eight-node shell model of $\mathrm{T} 85 \times 0,72$ sheet with a length of $5.0 \mathrm{~m}$. The sheet was loaded $1 \mathrm{kN} / \mathrm{m}^{2}$ on the whole surface and placed on two profiles, which depending on the case were: both straight, straight and arc shaped with a radius of $2 \mathrm{~m}$ or $4 \mathrm{~m}$. In each of these three cases, there were considered rotations of the supporting profiles with respect to each other of the following angle: $0^{\circ}, 5^{\circ}, 10^{\circ}, 15^{\circ}, 20^{\circ}$. As a result effective stresses were obtained, of which mean ranged from 0.2 to $5 \mathrm{MPa}$, depending on the case. The analysis concluded that the effective stress rising with the increase of the angle of twist, both the mean and the extreme values. What is more, the greater the rotation angle, the greater the difference between the mean and maximum stress. The stresses were concentrated in locations of connectors. The analysis showed that the stress vary depending on types of the support and angles of twist. Knowing the steering angle of each fold in the shell, regardless of type of support, the width of the sheet and the increase in effective stress can be specified. There is therefore a close relationship between the change in the width of the folds and the change in stress.
\end{abstract}

Keywords: shaping of sheets, elastic deformation, FEM analysis, unit twist angle

Przestano do redakcji:30.05.2015

Przyjęto do druku:10.01.2016

DOI: $10.7862 / \mathrm{rb} .2015 .204$ 